\title{
Implementasi Model Pembelajaran Take and Give Pada Mata Pelajaran IPS Kelas V Di MI Ar-Rahim Arjasa
}

\author{
Agus Zainudin \\ Universitas Islam Jember \\ guszain90@gmail.com \\ DOI: $10.35719 /$ educare.v2i1.54
}

\begin{abstract}
This study is the result of research that describes the implementation of the Take and Give learning model in social studies subjects for class V at MI Ar-Rahim Arjasa. The learning process includes 3 stages, namely the planning, implementation, and evaluation stages. This study aims to answer based on the background described above, the formulation of the problem in this study are: 1. How is the preparation in implementing the Take and Social Studies learning model for class V at MI Ar-Rahim Arjasa? 2. What is the process of implementing the Take and Give learning model for class $V$ social studies at MI Ar-Rahim Arjasa? 3. How is the evaluation in implementing the Take and Give learning model for social studies class $V$ at MI Ar-Rahim Arjasa? The research method used is descriptive qualitative with data collection techniques using observation, interviews and documentation. The sources of data in this study were the Principal, Teachers and Students of class V social studies subject class V at MI ArRahim, and other supporting documents. The results of this study indicate: (1) The implementation of the Take and Give learning model at the preparation stage has met all the preparations well. (2) The process of implementing classroom learning makes the learning atmosphere fun and students become more active. (3) At the evaluation stage, all students have achieved the assessment criteria in 3 aspects of the assessment, namely attitudes, knowledge and skills.
\end{abstract}

Keywords:Learning model; Take and Give; Social studies lessons 


\begin{abstract}
Abstrak
Penelitian ini adalah hasil penelitian yang mengurai tentang implementasi model pembelajaran Take and Give pada mata pelajaran IPS kelas V di MI Ar-Rahim Arjasa. Proses pembelajaran tersebut meliputi 3 tahap, yaitu tahap perencanaan, pelaksanaan, dan evaluasi. Adapun penelitian ini bertujuan untuk menjawab berdasarkan latar belakang yang telah dipaparkan di atas, maka rumusan masalah dalam penelitian ini adalah: 1. Bagaimana persiapan dalam mengimplementasikan model pembelajaran Take and pada mata pelajaran IPS kelas V di MI Ar-Rahim Arjasa? 2. Bagaimana proses dalam implementasi model pembelajaran Take and Give pada mata pelajaran IPS kelas V di MI Ar-Rahim Arjasa? 3. Bagaimana evaluasi dalam mengimplementasikan model pembelajaran Take and Give pada mata pelajaran IPS kelas V di MI Ar-Rahim Arjasa? Metode penelitian yang digunakan adalah kualitatif deskriptif dengan teknik pengumpulan data menggunakan observasi, wawancara dan dokumentasi. Adapun sumber data dalam penelitian ini adalah Kepala Sekolah, Guru dan Peserta didik kelas V mata pelajaran IPS kelas V di MI Ar-Rahim, dan dokumen penunjang lainnya. Hasil penelitian ini menunjukkan: (1) Implementasi model pembelajaran Take and Give pada tahap persiapan sudah memenuhi segala persiapan dengan baik. (2) Proses pelaksanaan pembelajaran dikelas membuat suasana belajar menjadi menyenangkan dan peserta didik menjadi lebih aktif. (3) Pada tahap evaluasi semua peserta didik telah mencapai kriteria penilaian dalam 3 aspek penilaian yaitu sikap, pengetahuan dan keterampilan.
\end{abstract}

KataKunci: Model Pembelajaran; Take and Give; Pelajaran IPS

\title{
PENDAHULUAN
}

Pendidikan secara umum merupakan suatu aspek kehidupan yang sangat mendasar bagi pembangunan bangsa suatu negara. Dalam penyelenggarakan pendidikan di sekolah yang melibatkan guru sebagai pendidik dan peserta didik sebagai peserta didik, diwujudkan dengan adanya interaksi belajar mengajar atau proses pembelajaran. Dalam Undang-undang No. 20 Tahun 2003 tentang SISDIKNAS dalam pasal 1 disebutkan bahwa pendidikan merupakan usaha sadar dan terencana untuk mewujudkan suasana belajar dan proses pembelajaran agar peserta didik secara aktif mengembangkan potensi dirinya untuk mewujudkan potensi dirinya untuk 
memiliki kekuatan spiritual keagamaan, pengendalian diri, kepribadian, kecerdasan, akhlak mulia, serta keterampilan yang diperlukan dirinya, masyarakat, bangsa dan negara. ${ }^{1}$

Membahas masalah pembelajaran, pembelajaran yang digunakan saat ini adalah pembelajaran tematik.Pembelajaran tematik merupakan suatu model pembelajaran yang memadukan beberapa materi pembelajaran dari berbagai kompetensi dasar satu atau beberapa mata pelajaran. ${ }^{2}$ Berdasarkan pendapat lain, pembelajaran tematik dimaknai sebagai pembelajaran yang dirancang berdasarkan tema-tema tertentu, dalam pembahasannya tema itu ditinjau dari berbagai mata pelajaran. ${ }^{3}$

Berdasarkan dua pandangan di atas dapat disimpulkan bahwa pembelajaran tematik adalah suatu bentuk rancangan pembelajaran yang berbasis tema untuk mengaitkan beberapa mata pelajaran. Pembelajaran tematik merupakan suatu wahana pembelajaran yang diharapkan tumbuh seiring dengan perkembangan peserta didik dalam melihat diri dan lingkungannya. Dalam pembelajaran yang aktif, peserta didik dituntut untuk mengalami sendiri, berlatih, berkegiatan, sehingga baik daya pikir, emosional, dan keterampilan mereka dalam belajar terus berlatih. Peserta didik juga harus berpartisipasi dalam proses pembelajaran dengan melibatkan diri dalam berbagai jenis kegiatan sehingga secara fisik mereka merupakan bagian dari pembelajaran tersebut.

Jadi ketika berbicara mengenai pembelajaran, maka hal tersebut tidak dapat dipisahkan lagi dari kata belajar dan mengajar. Belajar menunjukkan aktivitas yang dilakukan oleh seseorang yang disadari atau disengaja. Aktivitas ini menunjuk pada keaktifan seseorang dalam melakukan aspek

\footnotetext{
${ }^{1}$ Undang-Undang Republik Indonesia Nomor 20 Tahun 2003 tentang Sistem Pendidikan Nasional

${ }^{2}$ Ani Kadarwati dan Ibadullah Mallawi, Pembelajaran Tematik (Konsep dan Aplikasi), (Magetan: CV. Ae Media Grafika, 2017), 3.

${ }^{3}$ Wahyuni, Hermin Tri dkk, Implementasi Pembelajaran Tematik Kelas 1 SD, (Edcomtech:Volume 1 Nomer 2, (2016), 129
} 
mental yang memungkinkan terjadinya perubahan pada dirinya. ${ }^{4}$ Jadi dapat disimpulkan belajar adalah suatu proses yang dilakukan individu untuk memperoleh suatu perubahan tingkah laku yang baru secara keseluruhan, sebagai hasil dari pengalaman individu itu sendiri dalam interaksi dengan lingkungan sekitarnya.

Belajar dapat dikatakan berhasil apabila peserta didik telah mampu menyerap pelajaran dan hasil penyerapan pelajaran itu merubah perilaku peserta didik sesuai tujuan pembelajaran. Terutama pada mata pelajaran yang diguanakan dalam Ujian Nasional, salah satunya IPA. Penilaian hasil belajar peserta didik sangat penting dan strategis dalam kegiatan belajar mengajar. Dengan penilaian hasil belajar maka dapat diketahui seberapa besar keberhasilan peserta didik yang menguasai materi yang telah diajarkan oleh guru.

Saat ini pendidikan di Indonesia menerapkan Kurikulum 2013. Kurikulum 2013 lebih kepada pendidikan karakter, menciptakan peserta didik lebih aktif dan kreatif dalam pembelajaran serta Suasana lingkungan pendidikan dapat membimbing peserta didik berperilaku jujur, disiplin dan semangat sehingga menjadi dasar untuk meningkatkan kualitas dirinya. ${ }^{5}$ Untuk membuat peserta didik aktif dan kreatif, perlu adanya pemilihan model pembelajaran yang tepat. Sebagaimana yang kita ketahui, bahwa model pembelajaran mengajar merupakan sasaran interaksi anatara guru dengan peserta didik dalam melakukan kegiatan belajar mengajar. Dengan demikian yang perlu diperhatikan adalah ketepatan sebuah model pembelajaran yang dipilih dengan tujuan, jenis, dan juga sifat materi pengajaran, serta kemampuan guru dalam memahami dan melaksanakan model pembelajaran tersebut.

\footnotetext{
${ }^{4}$ Aprida Pane dan Muhammad Darwis Dasopang, Belajar dan Pembelajaran, Jurnal Kajian Ilmu-Ilmu Keislaman Volume 03 Nomer 2, (2017), 335.

5 Agus Zainudin, Penanaman Nilai-nilai Religius dalam Membentuk Akhlak Karimah bagi Peserta Didik di MI Ar-Rahim Kecamatan Arjasa Kabupaten Jember. Jurnal

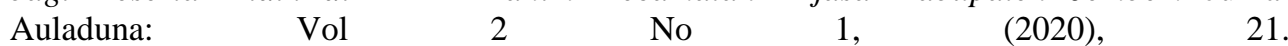
https://ejournal.inaifas.ac.id/index.php/auladuna/article/view/289/23
} 
Model pembelajaran adalah suatu perencanaan atau suatu pola yang digunakan sebagai pedoman dalam merencanakan pembelajaran di kelas atau pembelajaran dalam tutorial dan untuk menentukan perangkatperengkat pembelajaran termasuk di dalamnya buku-buku, film, komputer, kurikulum, dan lain-lain. ${ }^{6}$ Salah satu model pembelajaran yang membuat peserta didik lebih aktif yaitu model pembelajaran take and give.

Model pembelajaran take and give (menerima dan memberi) adalah dengan sintaks, siapkan kartu yang berisi nama peserta didik, bahan belajar, dan nama yang diberi, informasikan kompetensi, sajian materi, pada tahap pemantapan tapi peserta didik disuruh berdiri dan mencari teman dan saling informasi tentang materi atau pendalaman perluasannya kepada peserta didik lain kemudian mencatatnya pada kartu, dan seterusnya dengan peserta didik lain secara bergantian, evaluasi dan refleksi. ${ }^{7}$ Model pembelajaran tersebut merupakan salah satu tipe yang menekankan pada aktivitas dan interaksi diantara peserta didik untuk saling membantu dan menguasai materi pelajaran guna pencapaian prestasi yang maksimal. Dengan demikian komponen yang berperan penting dalam model pembelajaran take and give ini adalah penguasaan materi melalui kartu, berpasangan dengan saling bertukar informasi dan evaluasi yang bertujuan untuk mengetahui pengetahuan atau penguasaan peserta didik terhadap materi yang diberikan di dalam kartu dan kartu pasangannya.

Alasan objektif tentang pemilihan judul sebagai suatu pertimbangan yang mendorong peneliti untuk melakukan penelitian, antara lain: (1) Pembelajaran kooperatif memberi peluang bagi peserta didik dari berbagai latar belakang dan kondisi untuk bekerja dengan saling bergantung pada tugas-tugas akademik dan melalui struktur penghargaan kooperatif akan belajar saling menghargai satu sama lain. (2) Penerapan model pembelajaran

\footnotetext{
${ }^{6}$ Ngalimun, Strategi dan Model Pembelajaran, (Yogyakarta: Aswaja Pressindo, 2012), 7 .

${ }^{7}$ Ibid. 179
} 
yang tepat memiliki pengaruh besar terhadap ketercapaian tujuan belajar. (3) Dalam penerapan kurikulum 2013 dibutuhkan model pembelajaran yang membuat peserta didik lebih aktif dalam pembelajaran. (4) Kurikulum 2013 mengedepankan pendidikan karakter yang mana dalam proses pelaksanaan model pembelajaran Take and Give mengajarkan peserta didik untuk bisa bertanggung jawab, bersosial dengan teman sekelas, dan melatih keberanian peserta didik untuk menyampaikan materi kepada peserta didik yang lain.Berdasarkan uraian tersebut peneliti tertarik untuk melakukan penelitian dengan judul: "Implementasi Model Pembelajaran Take and Give pada mata pelajaran IPS kelas V di MI Ar-Rahim Arjasa".

\section{METODE PENELITIAN}

Pendekatan yang digunakan dalam penelitian ini adalah pendekatan kualitatif deskriptif. Penelitian deskriptif kualitatif sebagai penelitian yang menghasilkan data deskriptif berupa kata-kata tertulis atau lisan dari orang-orang dan perilaku yang dapat diamati. ${ }^{8}$ Adapun jenis penelitian yang digunakan dalam penelitian ini adalah penelitian lapangan (field research) dengan pandangan fenomonologi karena peneliti berangkat ke lapangan untuk mengadakan pengamatan tentang suatu fenomena dalam suatu keadaan alamiah. ${ }^{9}$ Adapun teknik pengumpulan data menggunakan wawancara, observasi, dan dokumentasi dan keabsahan datanya menggunakan triangulasi sumber dan teknik. Sedangkan analisis data deskriptif yaitu menggunkan reduksi data meliputi penyelesaian dan penyederhanaan data. Tujuannya agar data terorganisir secara runtut dan utuh, dan data disajikan secara sistematis, selanjutnya data dianalisis secara kualitatif untuk mendeskripsikan fenomena yang terjadi. Penarikan kesimpulan dilakukan dengan membandingkan data yang dihasilkan. Selanjutnya, dilakukan verifikasi data dengan mengecek ulang data dan menguji keabsahannya dengan teori yang berhubungan dengan data yang ditemukan.

\footnotetext{
${ }^{8}$ Lexy, J Moleong, Metodologi Penelitian Kualitatif, (Bandung: Remaja Rosdakarya, 2019), 4.

${ }^{9}$ Musfiqon, Panduan Lengkap Metodologi Penelitian Pendidikan, (Jakarta: Prestasi Public Publiser, 2012), 56.
} 


\section{HASIL DAN PEMBAHASAN TEMUAN}

\section{Konsep Implementasi Pembelajaran Take and Give Pada Mata Pelajaran IPS Kelas V Di MI Ar-Rahim Arjasa}

Model pembelajaran tipe take and give adalah tipe pembelajaran yang mengajak peserta didik untuk saling berbagi mengenai materi yang disampaikan oleh guru dengan kata lain tipe ini melatih peserta didik terlibat secara aktif dalam menyampaikan materi yang mereka terima ke teman atau peserta didik yang lain secara berulang-ulang. ${ }^{10}$ Selain itu juga tipe take and give merupakan tipe pembelajaran yang memiliki tujuan untuk membangun suasana belajar yang dinamis, penuh semangat dan antusiasme serta menciptakan suasana belajar dari pasif ke aktif, dari jenuh menjadi riang, serta mempermudah mudah peserta didik mengingat materi. Tipe take and give ini diarahkan agar tujuan belajar dapat dicapai secara efisien dan efektif dalam suasana yang gembira meskipun membahas hal-hal yang sulit dan berat. Hal tersebut di atas sejalan dengan teori Slavin, bahwa model pembelajaran take and give pada dasarnya mengacu pada konstruktivisme, yaitu pembelajaran yang dapat membuat peserta didik itu sendiri aktif dan membangun pengetahuan yang akan menjadi miliknya. Dalam proses itu, peserta didik mengecek dan menyesuaikan pengetahuan baru yang dipelajari dengan kerangka bepikir yang telah mereka miliki. ${ }^{11}$

\section{Langkah-langkah Model Pembelajaran Take and Give}

Menurut Darmadi langkah-langkah pelaksanaan model pembelajaran take and give yakni sebagai berikut: ${ }^{12}$

\footnotetext{
${ }^{10}$ Perwiraga Hartami dkk, Penerapan Model Pembelajaran Kooperatif Tipe Take And Give Pada Materi Minyak Bumi di Kelas X MAN Sabang. (Banda Aceh: UIN Ar-Raniry, 2014), 171.

${ }^{11}$ Aris Shoimin, 68 Model Pembelajaran Inovatif dalam Kurikulum 2013. (Yogyakarta: ArRuzz Media, 2014),195.

${ }^{12}$ Darmadi, Pengembangan Model dan Metode Pembelajaran dalam Dinamika Belajar Peserta didik.(Sleman: CV. Budi Utama, 2017), 57.
} 
a. Buat kartu ukuran $\pm 10 \times 15 \mathrm{~cm}$ sejumlah peserta didik, tiap kartu berisi sub materi (yang berbeda dengan kartu yang lainnya, materi sesuai dengan TPK);

b. Siapkan kelas sebagaimana mestinya;

c. Jelaskan materi sesuai kompetensi yang ingin dicapai;

d. Untuk memantapkan penguasaan peserta didik, tiap peserta didik diberi masing-masing satu kartu untuk dipelajari (dihapal) lebih kurang 5 menit;

e. Semua peserta didik disuruh berdiri dan mencari pasangan untuk saling menginformasi. Tiap peserta didik harus mencatat nama pasangannya pada kartu contoh;

f. Demikian seterusnya sampai tiap peserta didik dapat saling memberi dan menerima materi masing-masing (take and give);

g. Untuk mengevaluasi keberhasilan berikan peserta didik pertanyaan yang tak sesuai dengan kartunya (kartu orang lain);

h. Strategi ini dapat dimodifikasi sesuai keadaan;

i. Kesimpulan.

\section{Teknis Pelaksanaan Model Pembelajaran Take and Give}

Teknis pelaksanaan model pembelajaran take and give tersusun dari 7 langkah. Langkah-langkah tersebut diantaranya sebagai berikut:

a. Guru menyiapkan kelas sebagaimana mestinya dan menjelaskan tujuan pembelajaran serta menjelaskan model pembelajaran yang akan dilaksanakan;

b. Untuk memantapkan penguasaan peserta didik akan materi yang sudah dijelaskan, setiap peserta didik diberikan satu kartu untuk dipelajari (dihadapi) selama 5 menit;

c. Kemudian perintahkanlah peserta didik untuk mencari pasangan untuk saling menginformasikan materi yang telah diterimanya;

d. Tiap peserta didik harus mencatat nama teman pasangannya pada kartu yang sudah diberikan; 
e. Demikian seterusnya sampai semua peserta didik dapat saling memberi dan menerima materi masing-masing (take and give);

f. Setelah selesai semua, guru mengevaluasi keberhasilan model pembelajaran take and give dengan memberikan peserta didik pertanyaan yang tidak sesuai dengan kartunya (kartu orang lain);

g. Guru dan peserta didik bersama-sama membuat kesimpulan mengenai materi yang telah didiskusikan dan setelah itu guru menutup pelajaran.

\section{Kelebihan dan Kelemahan Model Pembelajaran Take and Give}

Kelebihan model pembelajaran take and give diantanya adalah sebagai berikut: ${ }^{13}$ (1) Peserta didik akan lebih cepat memahami penguasaan materi dan informasi karena mendapatkan informasi dari guru dan peserta didik yang lain, (2) Dapat menghemat waktu dalam pemahaman dan penguasaan peserta didik akan informasi. Sedangkan kelemahan model pembelajaran take and give diantanya adalah sebagai berikut: ${ }^{14}$ (1) Keadaan kelas menjadi kurang kondusif saat mencari pasangan; (2) Kemampuan menyampaikan materi antarsesama peserta didik terkadang belum sesuai harapan, serta; (3) Jika informan keliru atau salah memberikan materi maka peserta didik penerima informasi akan salah pemahaman.

\section{Implementasi Model Pembelajaran Take and Give Pada Mata Pelajaran IPS Kelas V Di MI Ar-Rahim Arjasa}

Dari data yang diperoleh oleh peneliti maka dalam pembahasan ini akan diungkapkan tentang hasil penelitian tentang implementasi model pembelajaran Take and Give pada mata pelajaran IPS kelas V di MI ArRahim Arjasa Jember yang intinya adalah meningkatkan prestasi belajar peserta didik. Secara garis besar hasil penelitian ini membahas mengenai perencanaan, pelaksanaan dan evaluasi. Berikut ini adalah hasil penyajian dan analisis data yang telah dipaparkan sebelumnya:

\footnotetext{
${ }^{13}$ Imas Kurniasih dan Berlin Sani, Ragam Pengembangan Model Pembelajaran Untuk Peningkatan Profesionalitas Guru, (Kata Pena, 2015), 103.

${ }^{14}$ Imas Kurniasih dan Berlin Sani, Ragam Pengembangan Model Pembelajaran,103-104
} 


\section{Perencanaan Pembelajaran Take and Give Pada Mata Pelajaran IPS Kelas V di MI Ar-Rahim Arjasa}

Berdasarkan data yang didapat sebelumnya, pada tahap perencanaan dalam mengimplementasikan model pembelajaran Take and Give pada mata mata pelajaran IPS Kelas V di MI Ar-Rahim Arjasa Jember terlaksana dengan baik. Hal ini dibuktikan pada perangkat administrasi yang telah disusun oleh guru. Di dalamnya sudah dilengkapi dengan beberapa hal yang mencakup seluruh perangkat pembelajaran seperti program tahunan, program semester, silabus, rencana pelaksanaan pembelajaran (RPP), dan media pembelajaran.

Tahap persiapan dalam proses pembelajaran merupakan awal yang harus disusun sedemikian rupa sebelum melaksanakan pembelajaran di kelas. Yang dimaksud dengan tahap persiapan adalah perencanaan menyusun langkah-langkah yang akan dilaksanakan untuk mencapai suatu tujuan yang ditentukan, dalam hal ini guru menyusun langkah-langkah menyesuaikan dengan langkah-langkah yang ada dalam model pembelajaran Take and Give.

Perencanaan mengajar pada hakikatnya adalah menggambarkan tentang apa yang akan dilakukan. Dengan hal itu, perencanaan mengajar adalah menyiapkanlangkah-langkah yang akan dilakukan dalam kegiatan pembelajaran.

\section{Pelakasanaan Pembelajaran Take and GivePada Mata Pelajaran IPS} Kelas V di MI Ar-Rahim Arjasa

Berdasarkan data yang diperoleh mengenai proses pembelajaran, dengan mengimplementasikannya model pembelajaran Take and Give ini keaktifan peserta didik dalam mengikuti kegitan pembelajaran meningkat. Peserta didik merasa senang dan menikmati pembelajaran saat proses take and give. Peserta didik juga belajar bertanggung jawab pada diri sendiri dengan materi yang telah diterima untuk dipelajari lebih dalam sehingga ketika peserta didik tersebut menyampaikan materi ke peserta didik yang 
lain, peserta didik yang lain tersebut dapat memahaminya. Sehingga dalam proses take and give juga terjalin interaksi yang saling menguntungkan karena satu dengan yang lain saling bertukar materi untuk dipahami. Proses pembelajaran tersebut sejalan dengan pendapat Slavin, bahwa model pembelajaran take and give pada dasarnya mengacu pada konstruktivisme, yaitu pembelajaran yang dapat membuat peserta didik itu sendiri aktif dan membangun pengetahuan yang akan menjadi miliknya. Dalam proses itu, peserta didik mengecek dan menyesuaikan pengetahuan baru yang dipelajari dengan kerangka bepikir yang telah mereka miliki. ${ }^{15}$ Sedangkan guru memiliki tugas untuk mengawasi dan mengontrol berjalannya proses pembelajaran denngan menggunakan model pembelajaran take and give tersebut agar berjalan dengan baik, sehingga dapat mencapai tujuan pembelajaran yang sudah ditentukan.

Adapun teknis pelaksanaan model pembelajaran take and give tersusun dari 7 langkah. Langkah-langkah tersebut diantaranya sebagai berikut: (a) Guru menyiapkan kelas sebagaimana mestinya dan menjelaskan tujuan pembelajaran serta menjelaskan model pembelajaran yang akan dilaksanakan. (b) Untuk memantapkan penguasaan peserta didik akan materi yang sudah dijelaskan, setiap peserta didik diberikan satu kartu untuk dipelajari (dihadapi) selama 5 menit. (c) Kemudian perintahkanlah peserta didik untuk mencari pasangan untuk saling menginformasikan materi yang telah diterimanya. (d) Tiap peserta didik harus mencatat nama teman pasangannya pada kartu yang sudah diberikan. (e) Demikian seterusnya sampai semua peserta didik dapat saling memberi dan menerima materi masing-masing (take and give). (f) Setelah selesai semua, guru mengevaluasi keberhasilan model pembelajaran take and give dengan memberikan peserta didik pertanyaan yang tidak sesuai dengan kartunya (kartu orang lain). (g) Guru dan peserta didik bersama-sama membuat

${ }^{15}$ Aris Shoimin, 68 Model Pembelajaran Inovatifdalam Kurikulum 2013...195. 
kesimpulan mengenai materi yang telah didiskusikan dan setelah itu guru menutup pelajaran.

\section{EvaluasiPembelajaran Take and GivePada Mata Pelajaran IPS Kelas V di MI Ar-Rahim Arjasa}

Secara umum evaluasi bertujuan untuk melihat sejauhmana suatu kegiatan tertentu dapat mencapai tujuan yang telah ditentukan, dengan digunakannya evaluasi hasil dan evaluasi proses sama halnya dengan menggunakan tehnik tes dan non-tes. Hal ini sebagaimana di jelaskan oleh Moh. Sahlan tehnik tes adalah penilaian yang dilakukan dengan tes, baik itu tes tulis ataupun wawancara. Sedangkan tehnik non-tes adalah penilaian yang dilakukan tanpa melalui tes, biasanya digunakan untuk menilai karakteristik dari peserta didik, bisa melalui observasi, skala sikap, angket dan wawancara. ${ }^{16}$

Berdasarkan data yang telah diperoleh, data tersebut mendeskripsikan bahwa penilaian yang dilakukan menyesuaikan dengan yang diberlakukan dalam Kurikulum 2013 yaitu menilai dari 3 aspek diantaranya aspek sikap (afektif), aspek pengetahuan (kognitif), dan aspek keterampilan (psikomotor). Ketiga aspek tersebut juga memiliki kriteria-kriteria penilaiannya sendiri berdasarkan lembar penilaian yang tercantum dalam RPP. Proses evaluasi tidak berhenti sampai di sini, guru juga melakukan tindak lanjut yang didasarkan pada hasil evaluasi. Karena hasil evaluasi yang diperoleh peserta didik telah mencapai kriteria penilaian, guru mengambil tindak lanjut untuk melanjutkan pada materi berikutnya.

Berdasarkan analisis, tujuan dari evaluasi adalah untuk mengetahui kemampuan dan potensi yang dimiliki oleh peserta didik. Dari hasil evaluasi, guru IPS mengetahui bahwa kemampuan peserta didik dalam menyampaikan materi beragam. Dari pemaparan di atas dapat disimpulkan bahwa evaluasi dalam implementasi model pembelajaran Take and Give

\footnotetext{
${ }^{16}$ Moh. Sahlan, Evaluasi Pembelajaran: Panduan Praktis Bagi Pendidik Dan Calon Pendidik, (Jember: STAIN Jember, 2015), 107-177.
} 
pada mata pelajaran IPS kelas Vdi MI Ar-Rahim sesuai untuk mencapai kriteria-kriteria penilaian ketiga aspek yang sudah ditetapkan dalam RPP. Dari evaluasi juga dapat diketahui keberagaman kemampuan peserta didik dalam menyampaikan materi pada saat proses Take and Give.

\section{SIMPULAN}

Berdasarkan hasil penyajian dan analisis temuan penelitian,maka dapat disimpulkan sebagai berikut: (1) Perencanaan model pembelajaran Take and Givepada mata pelajaran IPS Kelas V di MI Ar-Rahim Arjasa, yaitu menyusun seluruh perangkat administrasi pembelajaran, dan menyiapkan media kartu Take and Give. Dalam menusun RPP yang digunakan sebagai acuan pelaksanaan pembelajaran juga menyertakan langkah-langkah sesuai dengan langkah-langkah yang ada dalam model pembelajaran Take and Give. (2) Pelaksanaan model pembelajaran Take and Givepada mata pelajaran IPS Kelas V di MI Ar-Rahim Arjasa, yaitu: membuat suasana pembelajaran menjadi menyenangkan sehingga peserta didik dapat aktif dalam proses pembelajaran dan mudah untuk memahami materi. Dengan mengimplementasikan model pembelajaran ini peserta didik dapat belajar untuk bertanggung jawab dan belajar cara menyampaikan materi kepada peserta didik lain hingga peserta didik lain memahaminya. Selain itu juga terjadi interaksi antar peserta didik yang saling menguntungkan karena antara peserta didik yang satu dengan yang lain saling take and give (menerima dan memberi) materi. (3) Evaluasi model pembelajaran Take and Give pada mata pelajaran IPS Kelas V di MI ArRahim Arjasa mengikuti aturan kurikulum yang diterapkan di madrasah yaitu Kurikulum 2013. Dalam kurikulum ini evaluasi mencakup 3 aspek, yaitu sikap (afektif), pengetahuan (kognitif), dan keterampilan (psikomotor). 


\section{DAFTARPUSTAKA}

Darmadi. Pengembangan Model dan Metode Pembelajaran dalam Dinamika Belajar Peserta didik. Sleman: CV. Budi Utama, 2017.

Hartami, Perwiraga dkk. Penerapan Model Pembelajaran Kooperatif Tipe Take and Give Pada Materi Minyak Bumi di Kelas X MAN Sabang. Lantanida Journal: Volume 2 Nomer 2, 2014.

Ani Kadarwati dan Ibadullah Mallawi. Pembelajaran Tematik (Konsep dan Aplikasi). Magetan: CV. Ae Media Grafika, 2017.

Imas Kurniasih dan Berlin Sani. Ragam Pengembangan Model Pembelajaran Untuk Peningkatan Profesionalitas Guru, Kata Pena, 2015.

Moleong, LexyJ. Metodologi PenelitianKualitatif. Bandung: Remaja Rosda Karya, 2019.

Musfiqon. Panduan Lengkap Metodologi Penelitian Pendidikan. Jakarta: Prestasi Public Publiser, 2012.

Ngalimun. Strategi dan Model Pembelajaran. Yogyakarta: Aswaja Pressindo, 2012.

Aprida Pane dan Muhammad Darwis Dasopang. Belajar dan Pembelajaran. Jurnal Kajian Ilmu-Ilmu Keislaman: Volume 03 Nomer 2, 2017.

Sahlan, Moh. Evaluasi Pembelajaran: Panduan Praktis Bagi Pendidik Dan Calon Pendidik. Jember: STAIN Jember, 2015.

Shoimin, Aris. 68 Model Pembelajaran Inovatif dalam Kurikulum 2013. Yogyakarta: Ar-Ruzz Media, 2014.

Undang-Undang Republik Indonesia Nomor 20 Tahun 2003 tentang Sistem Pendidikan Nasional

Wahyuni, Hermin Tri dkk. Implementasi Pembelajaran Tematik Kelas 1 SD.II Edcomtech: Volume 1 Nomer 2, 2016.

Zainudin, Agus. Penanaman Nilai-nilai Religius dalam Membentuk Akhlak Karimah bagi Peserta Didik di MI Ar-Rahim Kecamatan Arjasa Kabupaten Jember. Jurnal Auladuna: Vol 2 No 1, 2020. 